\title{
Exploitative Use of Lexical Items in the Expression of Group Ideologies by the Late Ogoni Liberation Activist Ken Saro- Wiwa
}

\author{
Ibiere Ken-Maduako, Ph.D \\ Department of English, Ignatius Ajuru University of Education, Port Harcourt, Nigeria.
}

\begin{abstract}
This paper is an attempt to analyze one of Ken Saro-Wiwa's speeches made in his bid to effect justice and equity from the Federal Government of Nigeria to his oppressed people, the Ogonis of the Niger Delta region in Nigeria. The paper highlights the use of appropriate lexical items by the speaker to achieve specific aims. For instance, the lexical choice made by the speaker for the expression of group ideologies and for the expression of the ideological orientations of the Niger Delta struggle, such as resource control, self determination and environmental pollution. The main argument of this research is that language is a useful tool that can be employed in the conception, conduct and control of social conflict and that language is a significant instrument in socio- political discourse.
\end{abstract}

Keywords: Ideology, in-group, rut-group, Resource control, self- determination.

DOI: $10.7176 /$ JLLL/60-04

Publication date:September $30^{\text {th }} 2019$

\section{Introduction}

Language can be described as a very significant means of communication and a vehicle for conveying meaning and useful information and as a result of the significant function it plays in every human society, many believe that it is an indispensable tool to man. In another sense, language may be described as that electric current which if fully-charged, with expert wiring, can transmit fire likened to a volcanic eruption from speaker to his audience. Words have power if well utilized to evoke appropriate responses. Firth (1964:115) described language as that operator, switchboard and wiring that controls our social currents and power, the power and magic of speech being effective when it is able to mobilize feelings and action.

\section{Definition of Concepts}

\subsection{Conflict}

The word "conflict" can be used to denote differences and disagreements between two individuals, groups, states and nations. Conflict may involve differences of ideas, beliefs and principles or clashes between idealists and practicalists, between leftists and idealists, between liberalists and conservationists and many other groups that exist globally. Psychological conflicts may also occur in the form of natural struggles within an individual as a result of some unconscious opposition between ideas, impulses and desires stored deep within.

Conflicts usually occur when there are misunderstandings, disagreements, oppositions, disharmony, rivalry, and differences in opinion, hostilities and conflicts of interest between two individuals or groups. At another level, conflicts may also be defined in relation to war between two opposing forces or groups. That is, disagreements between two states, nations or tribes which sometimes result to wars as we find in many nations of Africa. The kind of conflict that this paper is concerned with is that between the Niger Delta people, represented by Ken saro-Wiwa and the Federal government of Nigeria along with their allies the multi- national oil companies in the region who are involved in oil exploration and exploitation

\subsection{The language of conflict}

Since conflicts result from disagreements, expectedly the language used in conflict situations should be antagonistic, contradictory, full of hate and revenge, defiant, contentious, hostile, pugnacious, quarrelsome, etc. During the Gulf War between the United States and Iraq, Radio Baghdad exhorted the Iraqi troops to:

Strike and the whole of Iraq and the faithful will be on your side

(ken- Maduako 2003:103).

Saddam Hussein on the other hand declared that:

The mother of wars has started

And reiterated that:

This will not be a picnic war for the Americans.

The choice of words revealed in the above statements confirms Iraqi defiance against the American-led United Nations Force. In this research, the major concern is with the language used by one of the major actors in the Niger Delta conflict, Ken Saro- Wiwa. 


\subsection{Language and ideology}

Language is intricately linked with ideologies because it functions as means through which people express ideas, beliefs and myths. Language is used to reflect social and political powers and to impact on such social and political structures. It is an indicator of both social and political situation and it can be used as an agent to change different political and social systems. Language is the chief instrument to be used for enlightenment, for democracy, and for human rights advocacy. This means that language has a fundamental relationship with ideology, beliefs and myths, being the chief agent for their propagation. It is important at this juncture to state that ideologies are usually expressed and embedded in discourse as different augmentative patterns, topics which have certain impact on readers and listeners. Meanings embodied in ideologies are often context dependent as different arguments may specify different meanings from context to context and in different historical periods or socio-political contexts. According to Zaidi (2012:71):

Language and ideology as an instrument in the hands of the powerful has an overarching hold on people... It is through the combine of language and ideology that status quo is maintained in society and truths and falsehoods are spread and crystallized. As can be understood from examples collected by some of the foremost voices of our time, the transformative power of language of ideology or ideology of language is vast, strong and lasting. Zaidi (2012:71)

In other words, ideology is a complex notion which creeps in socially and politically. As a social concept, it deals with social relations, consciences and power struggle. In the area of politics, ideology can be seen as a mechanism through which one ruling class attempts to deceive and control the masses.

\section{The Niger Delta: Background to the Study}

The Niger Delta is the estuary of the River Niger. It covers an area of over 70,000 square kilometers, covering a great portion of the South-South region of the country It has a population of about fifteen (15) million people and more than forty (40) ethnic groups with links to the linguistic groups of Ijaw, Edo, Igbo, Efik, Ibibio and Oron.(Ejibunu, 2007:7). It rises from The Kurukuru Hills and the Futa Jallon Mountains in Sierra Leone, runs east and then south joining the Benue River. The River Benue itself rises from the Adamawa Mountains in the Niger-Cameroun border. The two rivers are joined together at Lokoja forming a great body of river which, flows southwards. It is segmented into a number of creeks and rivulets which are emptied into the Atlantic Ocean. These creeks and rivulets make up the Niger Delta (Ejituwu, 2003:9). Debris flowing from thousands of miles away is deposited in these creeks and rivulets, serving as nutrients for the fish and other aquatic creatures in the river. For a very long period of time, these aquatic creatures died and accumulated and degenerated into what is termed today as "crude oil". The Niger Delta can be described as the largest wetland in Africa. It is rich in both renewable and non-renewable natural resources in the forms of oil, gas, bitumen, timber forest and non- timber forest products, wildlife, etc.

The basic occupations of the people at that time were fishing and salt-making. But with the influx of European merchants into the area in the $15^{\text {th }}$ century, slave trade was introduced and at a later date, trade in palm oil also became part of the people's occupation. According to Dike (1956:19), by 1830 the Niger Delta had become the greatest single trading region in West African (Ejituwu 2003: 2).

As the palm-oil trade thrived, the European merchants aware of certain advantages, sought to take over control of the trade. This resulted in conflict between the Delta chiefs and the British traders. Based on this, the British Government established a consulate at Fernando Po in 1849, a consul was also chosen as mediator. But by 1885 , the British government seized political independence from the Delta chiefs and constituted a protectorate over the area.

After independence in 1960, Nigeria became a sovereign nation. But during the pre-independence deliberations, the Niger Delta chiefs fully aware of the oil producing potentials of the area, did not ask for sovereignty but instead opted for a state within Nigeria. Asking for sovereignty would not have been outrageous because Kuwait is still an example of a small country which was carved out of Saudi Arabia. In the words of Ejituwu 2003:3,

\section{This action of the chiefs was simply nationalistic, and derived from their optimism}

that the Niger Delta would be better off staying with Nigeria.

Their request was denied and instead, the Sir Henry Willink Minorities Commission of 1958 recommended that it be made a "special area" within Nigeria. From then on, the people of the Niger Delta have gone through one nightmare or the other as oil became a dominant feature in the Nation's politics. Seven states in the country make up the Niger Delta Region; Akwa Ibom, Bayelsa, Cross River, Edo, Delta, Rivers and Ondo- these are described as the littoral states (Ejibunu:2007:7). Other states which also produce oil but which are not in the Niger Delta are: Abia and Imo states. Most of the oil companies in the country are situated in three states; Bayelsa, Delta and Rivers states, probably because most of the oil wells are also located in them. Since the activities of the oil companies are felt more in these states, they experience more drilling activities with their 
attendant effects on the environment and people, the demand for the control of their oil wells is more volatile the three states mentioned above.

This was the situation that precipitated the conflict. When the people realized that the government was not responding to their peaceful demands and had gone ahead to arrest and even kill some of their activists, the people responded and that was the beginning of the conflict in the Niger Delta region. Different people from different sides of the conflict said different things in their bid to end the conflict but our research interest is with the speech made by Ken Saro-Wiwa.

\subsection{Ken Saro-Wiwa's Speech: His Last Interview (Part 1):}

To deny a people the right to self determination for the past 110 years is to subject them to slavery. To take away the resources of a people and refuse to give them anything in return is to subject them to slavery. To take away the land of a people who depend solely on land for their survival and refuse to pay them compensation is to subject them to genocide.

I accuse the ethnic majority of practicing genocide against the Ogoni people. I accuse the oil companies who prospect for oil in Ogoni of encouraging genocide against the Ogoni people. I accuse shell and chevron of practising racism against the Ogoni people because they do in Ogoni what they do not do in other parts of the world where they prospect for oil.

The devastation of the Ogoni countryside, the complete destruction of the Ogoni ecosystem, the dehumanization of the Ogoni people, the denial to them of education and other health facilities and other social amenities, all these together have led the Ogoni down the way of extinction.

I accuse the Nigerian government and the international multi-national companies who prospect for oil in Ogoni of genocide.

I appeal to the international community, to the British government, the American government, the Japanese government, the countries of the European communities... to come now to the aid of the Ogoni people.

\section{Analysis of Speech by Ken Saro-Wiwa}

In the above text, we observe a demonstration of Van Dijk's (1984:137) belief that the myths, history and ideology define who the members of a culture are, their origin and their destiny. In Ken Saro-Wiwa's speech, there is a marked clear-cut distinction of the two sides of the divide because he clearly called them by their names and accused them of genocide and racism against his in-group, the Ogoni. The out-group members for him (we presume) are the ethnic majority (Igbo, Yoruba, Hausa), Shell and Chevron and the Nigerian government.

His speech begins with declarative statements which in turn are introduced by non-finite infinitive verbs.

To deny a people ... is to subject them to slavery

To take way the resources ... is to subject them to slavery.

To take away the land of... is to subject them to genocide.

Explicitly stated in this speech are the ideological orientations of the Niger Delta struggle which are; selfdetermination, resource control and environmental degradation or pollution. What we find here is a deliberate exploitation of discourse by Saro-Wiwa to separate his cultural in-group from certain out-groups in the society.

Furthermore, Chimombo and Roseberry (1998:15) noted that stereotypical cultural practices start with national origin and/or appearance which are the highest category in the hierarchical arrangement. As if in line with this argument, Saro-Wiwa accuses the multi-national oil companies of racism and of encouraging genocide against his in-group. That means these foreigners are different, they perform negative acts and even threaten his in-group's existence. Such description given about an out-group would normally evolve into ideologies and beliefs that function as basis for conflict. Usually, people begin to have negative conceptualization about an outgroup which are expressed in discourse and these subsequently become underlying conceptual models for wars and conflicts.

What comes out clearly from the above text is the significant role which language plays in socio-political discourse. Clinton (1997:174) argues that language plays significant roles in the emergence and conduct of social conflict. This is because abstract forms of conceptualizations that are derived from language and discourse revealed in ideologies and statements of beliefs can be used for the establishment and sustenance of independent states or for the purposes of wars.

Let us now consider Saro-Wiwa’s lexical choice. "to deny", "the right", "to self-determination", "to subject 
them" "to slavery", "to take away", "refuse", "to pay them", "to subject them", "to genocide". Genocide means deliberate murder of an entire community and to "subject" them to death implies that the people are forcefully eliminated, something like an ethnic cleansing.

In the second paragraph, Wiwa begins his accusation, but worthy of mention is the fact that the communal sense of "a people" is lost here. Wiwa singles himself out here by his lexical choice of the personal pronoun "I" in "I accuse...", "I accuse...". This is quite remarkable. Saro-Wiwa may have seen himself as an embodiment of the Ogoni people and culture, a representative of the Ogoni clan and nationality, to have singled himself out in this way. Curiously, in media reports the case between the Ogoni and Shell was reported as "Wiwa vs Shell". Can we then assume that taking him out of the way subsequently became one of the major preoccupations of the out-group? Still on Wiwa's choice of words, we observe his use of words that denote complete destruction in the third paragraph; "The devastation of the Ogoni...," "Complete destruction of", "dehumanization of", "the denial to them", etc.

Earlier, he had described the multi-national oil companies as "racists" because they were doing to the Ogoni what they would not dare to do in other "white" European countries where they prospect for oil. In the final paragraph, Saro-Wiwa appeals to the international community to come to the "aid" of the Ogoni people.

To express these ideological aspirations of the Ogoni, Saro-Wiwa employed different sentence patterns that would suit his purposes. The first paragraph consists of three simple declarative sentences with verbals introducing them. The infinitive phrases and their modifiers form the subject of the three sentences. They are brought to the sentence initial position by Wiwa for the purpose of foregrounding the activities he is condemning. Thus, we find the structures, "To deny... is", "to take away...is...". The second paragraph also consists of three accusations that begin with the expression. "I accuse..." These conform to Searle's declarations which changed the state of affairs of the accused people in the eyes of the Ogoni. They were thereby accused of the offences listed against them. The third paragraph consists of a simple sentence with a complex subject structure, pragmatically appropriate to suit the complexities of the sufferings and deprivation of the Ogoni people.

\section{Conclusion}

What we have tried to do here is to explore how language has been used to expose the ideological orientation of a people. It is not a wonder then that Ken Saro-Wiwa; after his peaceful means of protest and dialogue had failed, when arrested and tried by the military tribunal set up by General Sani Abacha had this to say:

My Lord, we all stand before history. I am a man of peace, of ideas, appalled by the denigrating poverty of my people who live on a richly endowed land, distressed by their political marginalization and economic strangulation, angered by the devastation of their land, their ultimate heritage, anxious to preserve their right to life and to a decent living...

(Source: Saro-Wiwa, http://www.unitedyawstates.com).

Saro-Wiwa's lexical choices are of utmost significance here. He describes himself as a man who was "appalled", "distressed", "angered" and "anxious." He is "a man of peace" and "of ideas". Finally, he includes everyone (both judges and crew (out-group), himself and his team (in-group), in the following words; "My lord, we all stand before history". History will exonerate, vindicate and condemn each man accordingly.

Considered on a fuller scale, the beliefs and ideologies of the people of the Niger Delta found full expression in some of the declarations made by the Ogoni and Ijaw ethnic nationalities in the Ogoni Bill of Rights (1990) and the Kaiama declaration (1998). Omotola (2008:804-810) expressed the opinion that the Ogoni Bill of Rights was at a point the main focus of the Ogoni struggle. Their leader, Ken Saro-Wiwa had been a human rights and environmental activist who had connections with both the international media, the human rights community and the environmental protection organizations. Saro-Wiwa was able to (given his affiliations with the above organizations) mobilize actions both locally and internationally.

\section{References}

Ayoola, K. A. (2005). Interpreting Nigerian Political Discourse: A Study of President Olusegun Obasanjo July 26, 2005 Address to Nigeria's National Assembly in Papers in English and Lingustics Vol. 6-2005.

Brown P. and S. Levenson (1987). Politeness: Some University in language. Cambridge: Causing University Press.

Bartsch. R. (1979). "Semantically and pragmatically correctness as Basic Notions of the Theory of Meaning", in Journal of Pragmatics Vol.3

Bell-Gam, I. (1991). "What is it for Anything to have Meaning at all?" Unpublished paper in Department of English, University of Ibadan.

Code, D. (1980). "Language and Knowledge" in Word Vol.31.

Cooper, D. E. (1973). "How to do things with words" in Philosophy and the Nature of Language. London: Longman. 
Coulthard, M. (1977). An Introduction to Discourse Analysis. London: Longman.

Davis, S. (1979). "Perlocutions" in Linguistics and Philosophy Vol. 3. No.2

Dike, (1956). Trade and Politics in the Niger Delta. Oxford: Oxford University Press.

Ejituwu, N.C. (2003). Niger Delta Development Commission: Problems and Prospects in the Niger Delta Region. Journal of Pedagogy and Development. Vol. 3. No. 1. pp 1-13.

Ayoola, K. A. (2005). Interpreting Nigerian Political Discourse: A Study of President Olusegun Obasanjo July 26, 2005 Address to Nigeria's National Assembly in Papers in English and Lingustics Vol. 6-2005.

Brown P. and S. Levenson (1987). Politeness: some University in language. Cambridge: Causing University Press.

Bartsch. R. (1979). "Semantically and pragmatically correctness as Basic Notions of the Theory of Meaning", in Journal of Pragmatics Vol.3

Bell-Gam, I. (1991). "What is it for Anything to have Meaning at all?" Unpublished paper in Department of English, University of Ibadan.

Code, D. (1980). "Language and Knowledge" in Word Vol.31.

Cooper, D. E. (1973). "How to do things with words" in Philosophy and the Nature of Language. London: Longman.

Coulthard, M. (1977). An Introduction to Discourse Analysis. London: Longman.

Davis, S. (1979). "Perlocutions" in Linguistics and Philosophy Vol. 3. No.2

Dike, (1956). Trade and Politics in the Niger Delta. Oxford: Oxford University Press.

Ejituwu, N.C. (2003). Niger Delta Development Commission: Problems and Prospects in the Niger Delta Region. Journal of Pedagogy and Development. Vol. 3. No. 1. pp 1-13. 